\title{
Quiste de Gorlin asociado a odontoma: reporte de un caso con su tratamiento quirúrgico
}

\author{
Gorlin cyst associated with odontoma: Case report with surgical treatment
}

\author{
P. Villarroel Castro ${ }^{1}$, R. Fariña Sirandoni ${ }^{2}$, I. Espinoza Santander ${ }^{3}$
}

Resumen: El quiste de Gorlin es un quiste odontogénico que puede presentarse en dos variedades, una quística rodeada por epitelio y de carácter benigno, y una neoplásica localmente agresiva. Se presenta elcaso de una mujer de 18 años con aumento de volumen facial indoloro en región infraorbitaria izquierda. Se realiza la exéresis total de la lesión. Con el estudio histopatológico se obtiene el diagnóstico definitivo de quiste de Gorlin asociado a odontoma. Luego de controles por 3 años, se observa el restablecimiento de la simetría facial, una adecuada regeneración ósea y de los tejidos adyacentes, sin signos de recidiva.

Palabras clave: Gorlin Cyst; Calcifying Odontogenic Cyst; Odontogenic cyst.

Recibido: 13.07 .05

Aceptado: 15.11 .05
Abstract: Gorlin cyst is an odontogenic cyst that may appear as two types, one cystic and surrounded by epithelium of a benign nature, and the other a locally aggressive neoplasm. The case is presented of an 18-year-old female that had experienced an increase in facial volume in the left infraorbital area that was painless. Total exeresis of the lesion was carried out. The histopathologic study provided the definitive diagnosis of Corlin cyst associated with odontoma. After a follow-up of three years, facial symmetry was reestablished, there was adequate regeneration of bone and of the adjacent tissue, and there were no signs of relapse.

Key words: Gorlin Cyst; Calcifying Odontogenic Cyst; Odontogenic Cyst.

\footnotetext{
1 Residente. Servicio de Cirugía Maxilofacial. Hospital Del Salvador.

2 Servicio de Cirugía Maxilofacial. Hospital Del Salvador; Unidad de Cirugía

Maxilofacial Hospital Exequiel González Cortés; Profesor del Departamento de

Cirugía Oral y Maxilofacial, Facultad de Odontología Universidad Mayor.

3 Profesor de Patología, Facultad de Odontología Universidad de Chile,

Santiago de Chile, Chile.
}

\section{Correspondencia:}

Dr Rodrigo Fariña Sirandoni

Avda. Providencia 2330 of. 23, Providencia

Santiago, Chile

Email: rofari@gmail.com; paula78cı@yahoo.com 


\section{Introducción}

El quiste de Gorlin es una lesión poco frecuente que se origina a partir de remanentes epiteliales derivados del proceso de odontogénesis. Generalmente se presenta como una lesión quística bien delimitada rodeada por un epitelio, con características poco invasivas, siendo considerada por éste motivo como una lesión benigna. También se ha encontrado como variedad no quística con un comportamiento localmente agresivo e infiltrando tejidos, siendo considerado en estos casos una neoplasia. ${ }^{1}$ El presente trabajo reporta el caso de un quiste de Gorlin ubicado en la región infraorbitaria izquierda, su tratamiento quirúrgico, resultado obtenido, además de una discusión sobre sus posibles diagnósticos diferenciales.

\section{Caso Clínico}

Se presenta el caso de una mujer de 18 años, quien consulta por un aumento de volumen facial ubicado en la región infraorbitaria izquierda, con una evolución de 6 meses aproximadamente y crecimiento lento. En sus antecedentes mórbidos no relata ninguno de importancia, no consume ningún tipo de medicamento ni presenta alergias conocidas.

Al examen facial se observa un aumento de volumen facial derecho, provocando la desaparición del surco nasogeniano y labiogeniano (Fig. 1), desplazamiento del ala nasal izquierda y desviación de la columela y punta nasal hacia la derecha (Fig. 2).

La piel que recubre la lesión es de aspecto normal, presentando en el momento de consultar un tamaño de $6 \mathrm{cms}$ de diámetro aproximadamente. A la palpación es indoloro y de consistencia firme.

Al examen intraoral se observa un aumento de volumen en el fondo del vestíbulo en relación a la fosa canina, recubierto por mucosa de características normales. No se observan signos de infección activa (Fig. 3). Las piezas dentarias en relación a la lesión se encuentran vitales y con ausencia de movilidad.

Al estudio de imagen, se observa en la radiografía panorámica una lesión radiolúcida, uniloculada, de $4 \times 5 \mathrm{~cm}$ de bordes bien definidos que se extiende desde mesial de la pieza 1,1 a distal de la 2,4, produciendo rizólisis de estas piezas dentarias. Se puede observar

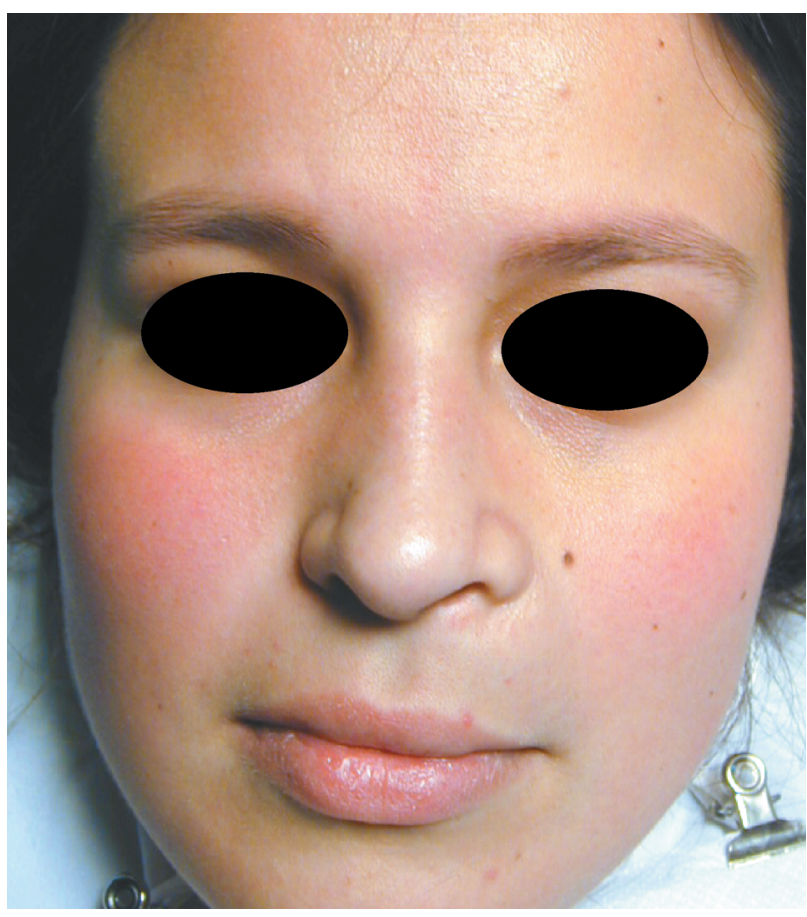

Figura 1. Vista frontal preoperatoria de la paciente. Figure 1. Preoperative frontal view of patient.

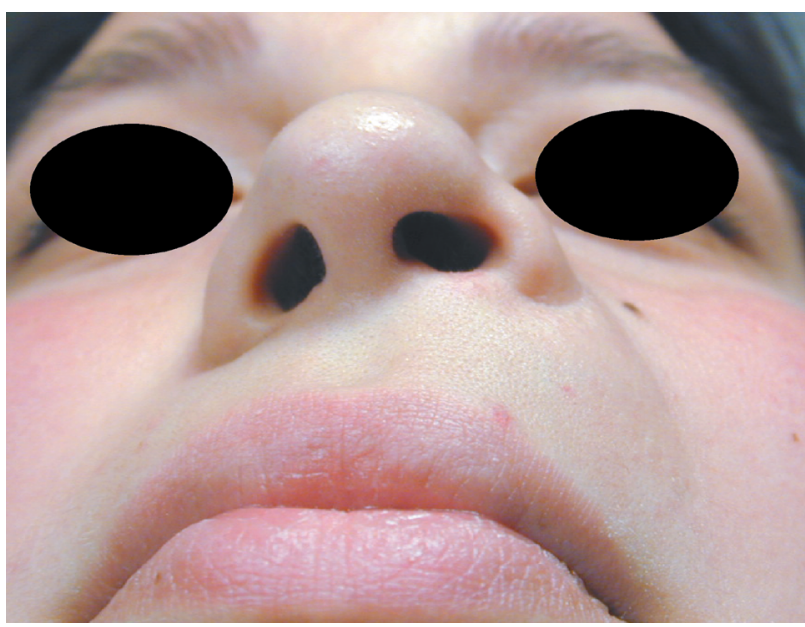

Figura 2. Vista inferior preoperatoria de la paciente.

Figure 2. Preoperative inferior view of patient.

\section{Introduction}

Gorlin cyst is an unusual lesion that arises as a result of epithelial remains associated with odontogenesis. It generally presents as a cystic lesion that is well-defined and surrounded by epithelium. It has less invasive characteristics and for this reason it is considered a benign lesion. $A$ non-cystic variety has also been found with behavior that is locally aggressive. It infiltrates tissues and in this case it is considered a neoplasm. ${ }^{1}$ This paper covers a case of Gorlin cyst located in the left infraorbital region, its surgical treatment, the results obtained, and the differential diagnoses that are possible are discussed.

\section{Case Report}

A young 18 year-old female presented with an increase in facial volume in the left infraorbital region that had been growing slowly for six months. Her medical history was insignificant, she was not taking any medication and she had no known allergies. The facial examination showed an increase in facial volume on the right side that had lead the disappearance of the naso-labial fold (Fig. 1), displacement of the left nasal wing and deviation of the columella and nasal tip towards the right side (Fig. 2).

The skin covering the lesion was of a normal appearance, and on consultation it measured $6 \mathrm{~cm}$ in diameter approximately. On palpation it was painless and it was firm in consistency.

The intraoral examination revealed an increase in volume at the back of the cavity in relation to the canine fossa. The area was covered with mucosa of normal characteristics and there were no signs of active infection (Fig. 3). The teeth by the lesion were vital and there was no mobility. 
también una pequeña zona radiopaca aislada inmersa en la lesión (Fig. 4).

En la tomografía axial computarizada (TC), con cortes coronales y axiales (Fig. 5), se observa en la zona anterior izquierda del maxilar, una lesión redondeada, bien delimitada, corticalizada y con aparente contenido líquido.

Para el tratamiento quirúrgico se realizó un abordaje transoral mediante un colgajo crevicular con dos descargas verticales. Al exponer la zona se observó un tejido óseo papiráceo y crepitante, que cubría una lesión de aspecto quístico y consistencia depresible recubierta por una cápsula fibrosa.

Siguiendo el plano de clivaje se realizó la excéresis completa de la lesión (Fig. 6). Se realizó el cierre en un plano (Fig. 7), y se dejó gasa yodoformada cual se retiró progresivamente durante 2 semanas (Fig. 8).

Al estudio macroscópico de la pieza operatoria se observa una lesión quística rodeada por una cápsula fibrosa en la que se encontraba una pequeña calcificación. En su interior se encuentra contenida una sustancia acuosa de color café parduzco (Fig. 9).

Al estudio histopatológico se observa una lesión quística bien definida que presenta una cápsula fibrosa y un epitelio constituido por células basales cúbicas, células con aspecto de retículo estrellado y otras que aparecen como masas de células fantasmas. El fragmento calcificado adosado a la pared del quiste presentaba al examen microscópico las características de un odontoma, con una zona central de tejido conjuntivo similar al de la pulpa dental, dentina y esmalte inmaduro que se fusiona con otros tejidos mineralizados que tienen el aspecto de gránulos basófilos y tejido dentinoide (Fig. 10). Según el estudio histopatológico la lesión corresponde a un quiste de Gorlin asociado a odontoma.

Dos semanas luego de la excisión quirúrgica, se puede observar el cierre completo de la mucosa y el restablecimiento de la simetría facial (Fig. 8). Luego de un seguimiento de tres años, no se observa recidiva (Fig. 11).

\section{Discusión}

Según Curran, en un espacio folicular ensanchado mayor a 5 $\mathrm{mm}$ es posible sospechar de un quiste o tumor odontogénico. ${ }^{2,3}$

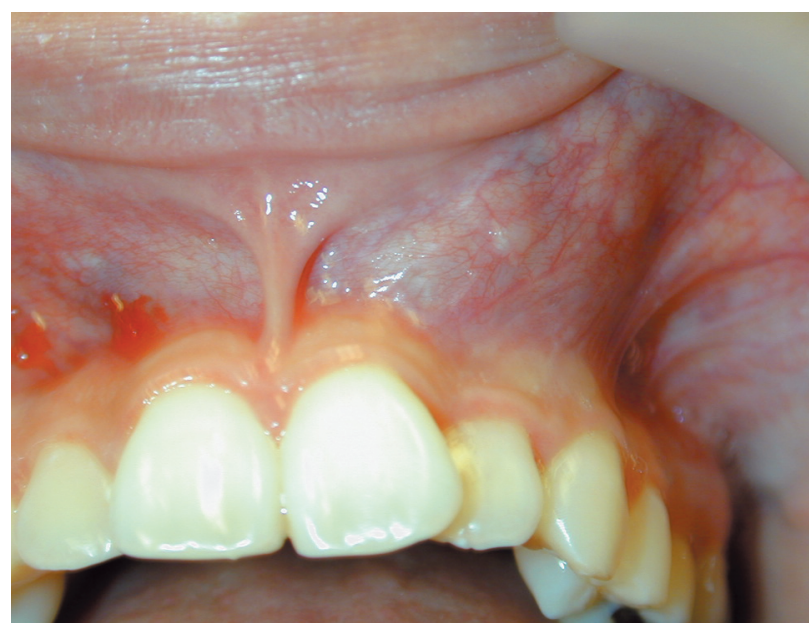

Figura 3. Vista intraoral preoperatoria. Fondo del vestíbulo, en relación a la fosa canina lado izquierdo.

Figure 3. Preoperative intraoral view. Back of vestibule, in relation with the canine fossa, left side.

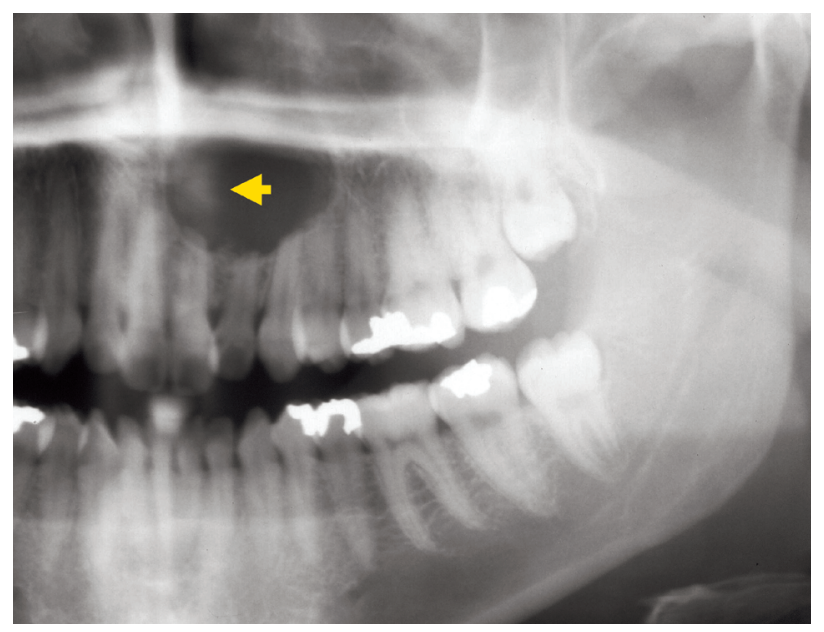

Figura 4. Radiografía panorámica: se observa lesión radiolúcida unilocular, bien definida en zona maxilar izquierda entre pzas 1.1 a 2.4. Inmerso en la lesión pequeña área radiopaca (flecha).

Figure 4. Panoramic radiography showing radiolucid, unilocular lesion that is well-defined in the left maxillary area between teeth nos. 1.1 and 2.4. A small radiopaque area can be observed in the lesion (arrow).
The imaging study by panoramic radiography showed a radiolucid, unilocular lesion that measured 4 $\times 5 \mathrm{~cm}$, with well-defined borders. It extended from the mesial tooth 1.1 to the distal tooth 2.4 , producing rhizolysis in the teeth. A small, isolated, radiopaque area could be seen in the lesion (Fig. 4). The computed axial tomography (CT) with coronal and axial views (Fig. 5) showed in the left anterior region of the maxilla, a rounded lesion that was well-defined, corticalized and with a seemingly liquid content.

A transoral approach was used for the surgical treatment by means of a crevicular flap with two vertical incisions. Once the area was exposed, bone tissue covering the lesion could be observed that was papery and crepitant. It had a cystic appearance and a soft consistency, and it was covered by a fibrous capsule.

The lesion was completely removed along the cleavage plane (Fig. 6). One layer was closed (Fig. 7), and iodoform gauze was left and gradually removed over the following two weeks (Fig. 8).

The macroscopic examination of the surgical specimen revealed a cystic lesion surrounded by a fibrous capsule containing a small calcification. There was a watery, coffeecolored substance inside it (Fig. 9).

The histopathologic examination revealed a well-defined cystic lesion that was surrounded by a fibrous capsule and epithelium that was made up of cuboidal basal cells, cells with a stellate reticulum-like appearance and others with the appearance of ghost cells. The calcified fragment that was attached to the cyst wall seemed, when examined microscopically, to be an odontoma with a central area of conjunctive tissue similar to dental pulp, dentine and immature enamel. It was fused with other mineralized tissue that had the appearance of basophilic granules and dentin tissue (Fig. 10). According to the histopathologic study the lesion corresponded to a Gorlin 
En un estudio retrospectivo de 2.645 casos de piezas incluídas, se encontraron estos tipos de lesiones patológicas en un $32,9 \%$ de los casos. ${ }^{2}$ Basado en los hallazgos disponibles, es posible realizar un diagnóstico diferencial entre las siguientes entidades patológicas:

- Quiste dentígero (QD). Es el quiste odontogénico más frecuente después del quiste radicular, correspondiendo al $20 \%$ de los quistes epiteliales de los maxilares. Es una lesión benigna asociada a la corona de dientes permanentes, ${ }^{4}$ o supernumerarios no erupcionados. Puede estar asociado a odontomas y raras veces a dientes temporales. ${ }^{1,4,5}$ Los más pequeños son asintomáticos, sin embargo, los de mayor tamaño pueden producir asimetrías faciales. Se presentan con mayor frecuencia en relación a terceros molares en mandíbula y en segundo lugar en la región canina del maxilar. $1,2,5$ Generalmente aparecen en la $2^{\underline{a}}$ década de vida, ${ }^{5,6}$ con una predilección por el sexo masculino $(1,6: 1) .1,5,6$ En la imagen radiográfica aparece como una imagen radiolúcida unilocular, de tamaño variable, con bordes bien definidos y corticalizados, asociada a la corona de una pieza dentaria incluída. 4,5,7

- Tumor odontogénico adenomatoide, variedad folicular (TOA). EI TOA folicular es una lesión intraósea asociada con una pieza no erupcionada, corresponde al $75 \%$ del total de TOAs. Afecta a individuos jóvenes, alrededor de la 2 da década, con una predilección por mujeres $(2: 1))^{1,8,9}$ Afectan de preferencia la zona anterior y más frecuentemente el maxi-

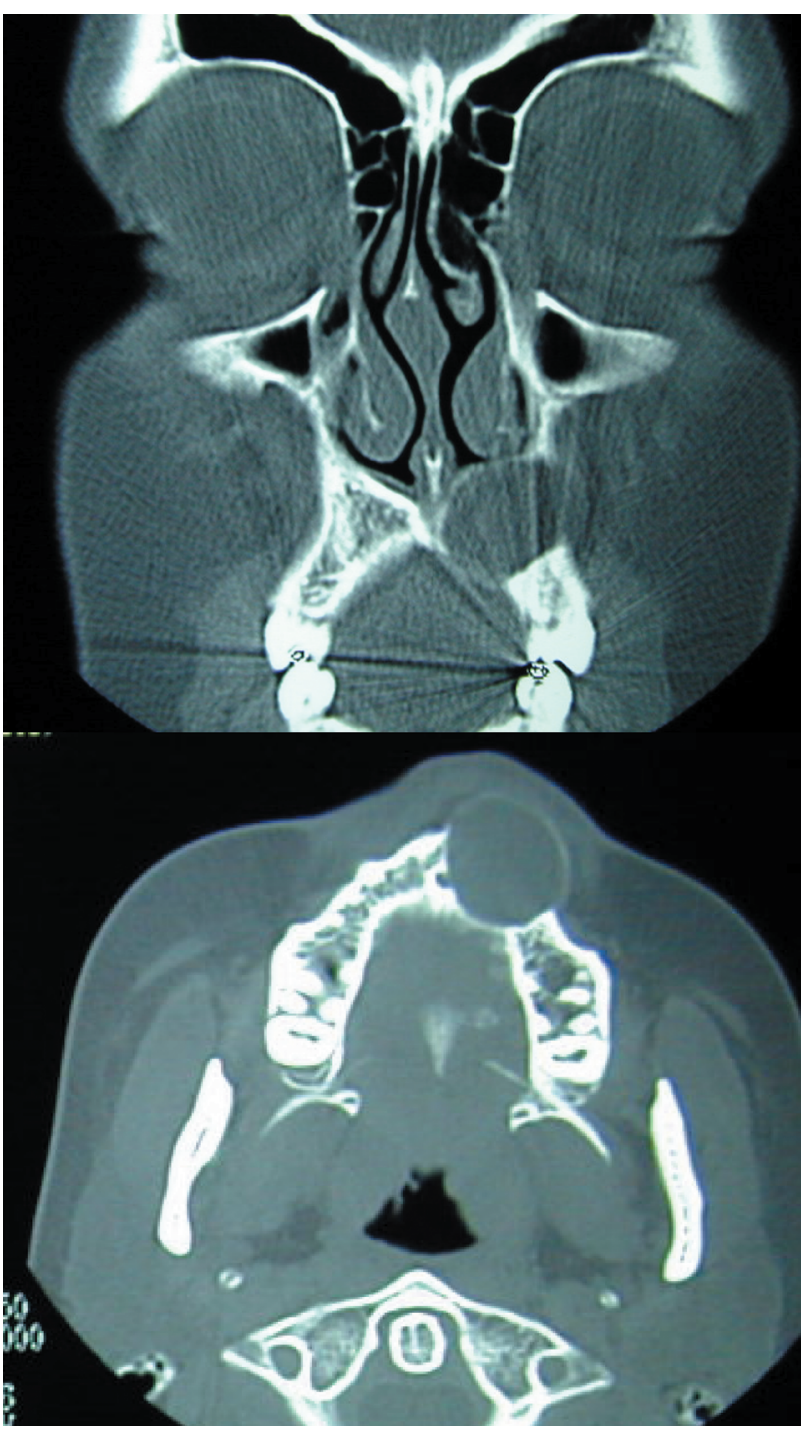

Figura 5. Tomografía axial computarizada (TC), abajo, corte axial, se observa la lesión abarcando el espesor del maxilar, provocando la expansión y adelgazamiento de la cortical externa. Arriba, corte coronal, se observa el desplazamiento del piso de la fosa nasal.

Figure 5. Computed axial tomography (CT) low, axial view, the lesion can be observed covering the thickness of the maxilla, leading to the expansion and thinning of the external cortical bone. Above, coronal view, showing displacement of the nasal fossa, floor of the nose. lar. ${ }^{1,9}$ Son asintomáticos y general-

mente no miden más de $3 \mathrm{~cm}$ de diámetro. Se distingue del QD ya que abarca además de la porción coronal, la porción radicular de la pieza incluida. 1,9

- Quiste odontogénico calcificante (quiste de Gorlin) (QG). El Quiste odontogénico epitelial calcificante o Quiste de Gorlin (QG) es una lesión que deriva de remanentes del epitelio odontogénico, por lo que es exclusivo de los maxilares. Fue descrito por primera vez como entidad patológica en 1962 por Gorlin y cols. ${ }^{13}$

Esta lesión es poco frecuente, corresponde al $1 \%$ de los quistes de los maxilares, ${ }^{6,10}$ y presenta una variada histología y manifestaciones clínicas. ${ }^{1}$ cyst associated with odontoma.

Two weeks after the surgical excision, the mucosa was completely closed and facial symmetry had been reestablished (Fig. 8). During the three year follow-up there was no relapse (Fig. 11).

\section{Discussion}

According to Curran, an odontogenic cyst or tumor can be suspected in a follicular space that has expanded to $5 \mathrm{~mm} .2,3$ In a retrospective study of 2.645 cases of embedded teeth other types of pathologic lesions were found in $32.9 \%$ of cases. ${ }^{2}$ Based on the available findings, a differential diagnosis can be made between the following pathologic entities:

- Dentigerous cyst (DC). This is the most common odontogenic cyst after the radicular cyst, accounting for $20 \%$ of the epithelial cysts of the maxilla. It is a benign lesion associated with the permanent dental crown ${ }^{4}$ or with non-erupted supernumeraries. It can be associated with odontomas and on rare occasions with temporary teeth. 1,4,5 The smaller ones are asymptomatic but the larger ones can produce facial asymmetries. They appear most commonly by the third molars of the mandible and secondly by the canine region of the maxilla. $1,2,5$ They generally appear in the second decade of life 5,6 and they have a predilection for the male sex $(1,6: 1), 1,5,6$ The radiographic image shows a radiolucid unilocular image of a varied size, with well-defined borders and corticalized, associated with the crown of a non-erupted tooth. $4,5,7$

- Adenomatoid odontogenic tumor, follicular variety (AOT). The follicular AOT is an intraosseous lesion associated with a non-erupted tooth, accounting for $75 \%$ of all AOTs. It affects young individuals, around the 2 nd decade in life, with a predilection for females (2:1) 1, 1,9 It main- 
La organización mundial de la salud (OMS) la describe como un quiste no neoplásico pero lo clasifica como un tumor benigno. ${ }^{14}$ Otros autores lo consideran como dos entidades, una variedad quística y otra variedad neoplásica. ${ }^{15-17}$

La variedad quística está rodeada por epitelio y es como se presenta entre un 80 a un $90 \%$ de los casos, sin embargo, entre un 2 y un $16 \%$ se presenta como variedad no quística, infiltrando tejidos, siendo localmente agresiva y de carácter maligno, considerado por este motivo una neoplasia. ${ }^{1}$

En este caso clínico lo observamos como variedad quística y como lesión intraósea, que es lo más frecuente según la literatura, existiendo entre un 12 a $21 \%$ de los casos que se presentan como lesión extraósea (periférica), 1,6,15,18,19 la que se manifiesta como una masa gingival sésil o pedunculada sin características clínicas que la distingan de un fibroma gingival, quiste o granuloma periférico de células gigantes. ${ }^{1}$ Ambos afectan con igual frecuencia tanto a la mandíbula como al maxilar.

En este paciente lo encontramos ubicado en el área incisiva-canina del maxilar siendo éste el lugar más afectado del maxilar, con una frecuencia del $65 \%$, según lo descrito en la literatura. $1,17,18$

La edad de la paciente coincide con la prevalencia reportada por otros autores, siendo esta lesión más prevalente durante la $2^{\underline{a}}$ y $3^{\underline{a}}$ década con una edad promedio de 33 años.1,17-19

Se ha visto asociado a ameloblastoma, fibroma ameloblástico, y odontoma complejo, este último especialmente en pacientes más jóvenes, como en éste caso, con una frecuencia de un 20 a $50 \%$ de los casos descritos en la literatura. 1,11,18-21 La variedad neoplásica generalmente se encuentra en pacientes mayores aunque es menos frecuente.

La radiografía no presenta una imagen característica, pudiendo mostrar una imagen uni o multiloculada. También es posible observar la presencia de calcificaciones de tamaños variables.

Con relación a las alternativas terapéuticas, todas se orientan a eliminar

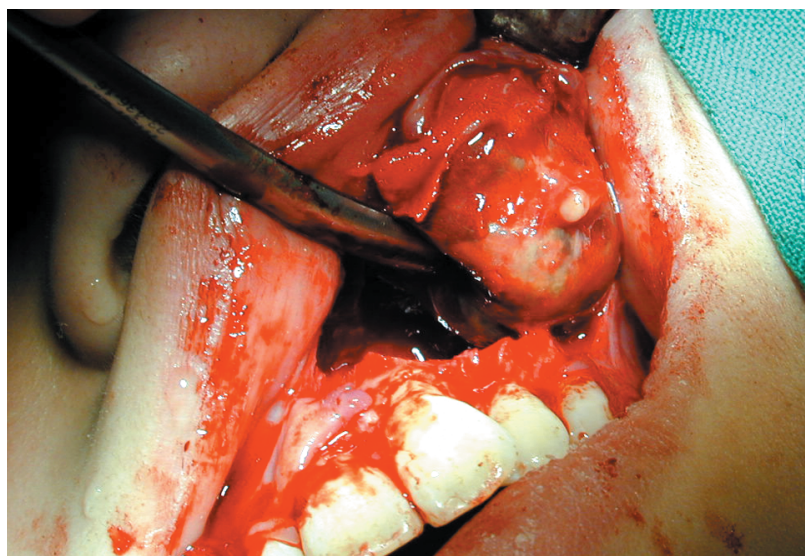

Figura 6. Enucleación de la lesión, en que se observa cápsula fibrosa y presencia de un tejido calcificado.

Figure 6. Enucleation of the lesion showing the fibrous capsule and the presence of calcified tissue.

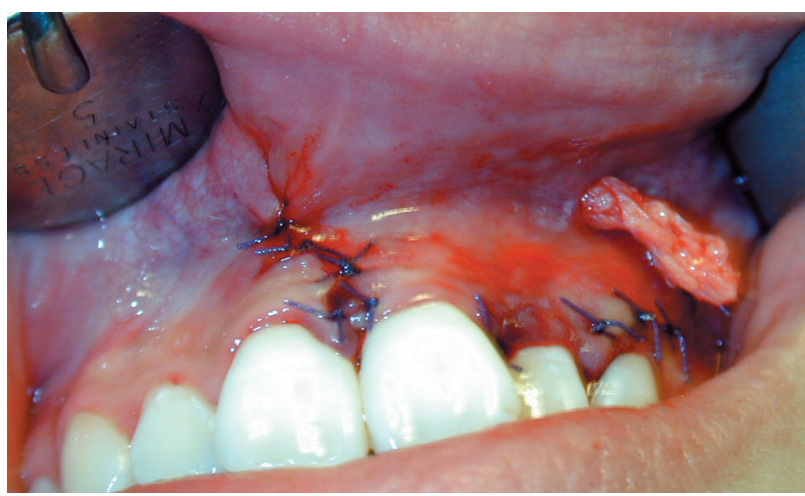

Figura 7. Postoperatorio intraoral 1 semana luego de cirugía. Figure 7. Postoperative intraoral view one week after surgery.

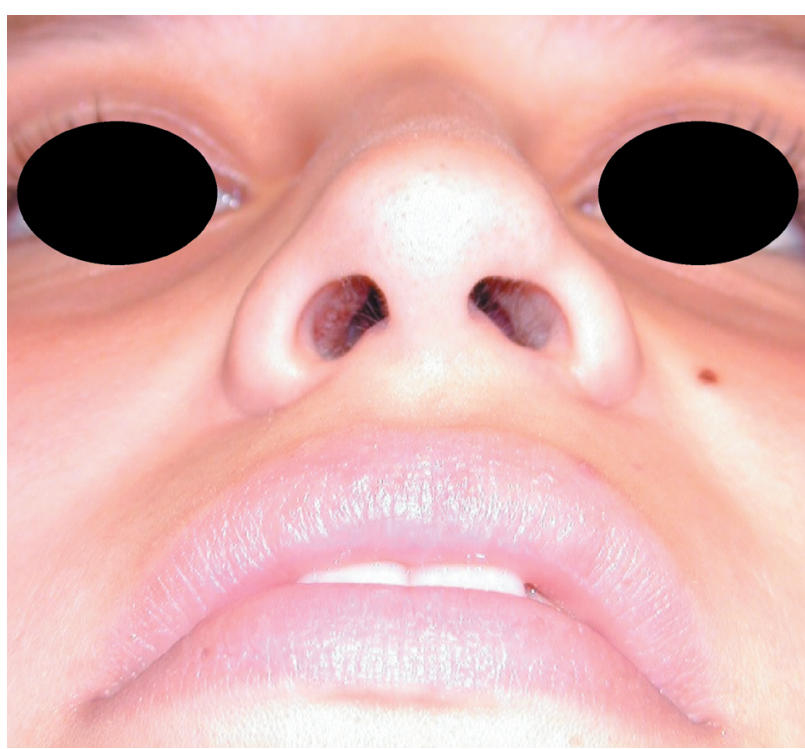

Figura 8. Postoperatorio aspecto facial 3 semanas luego de cirugía.

Figure 8. Postoperative facial appearance three weeks after surgery. ly affects the anterior area and it is commonly to be found in the maxilla. 1,9 It is asymptomatic and it generally does not measure more than $3 \mathrm{~cm}$ in diameter. It can be distinguished from the $G C$ in that in addition to covering the coronal portion, it covers the radicular portion of the embedded tooth.1,9

- Calcifying odontogenic cyst (Gorlin cyst) (GC). The calcifying epithelial odontogenic cyst or Gorlin cyst (GC) is a lesion that arises from the remains of odontogenic epithelium, and it is found exclusively in the maxilla. It was first described as a pathologic entity in 1962 by Gorlin el al. ${ }^{13}$

It is a very unusual lesion accounting for $1 \%$ of all maxillary cysts ${ }^{6,10}$ and its histology and clinical manifestations are varied. ${ }^{1}$ The world health organization (WHO) has described it as a non-neoplastic cyst but classifies it as a benign tumor. ${ }^{14}$ Other authors consider it as two entities, one cystic and the other neoplastic. ${ }^{15,17}$

The cystic variation is surrounded by epithelium and 80 to $90 \%$ of cases appear as such. However, between 2 and $16 \%$ present as the noncystic variety, infiltrating tissues, being locally aggressive and with malignant characteristics. For these reasons it is considered a neoplasm. ${ }^{1}$ In this clinical case we observed the cystic variety in the form of an intraosseous lesion which, according to the literature, is most common type. Between 12 and $21 \%$ of cases present as an extraosseous lesion (peripheral), 1,6,15,18,19 which manifest as a sessile or pedunculated gingival mass, with no clini- 

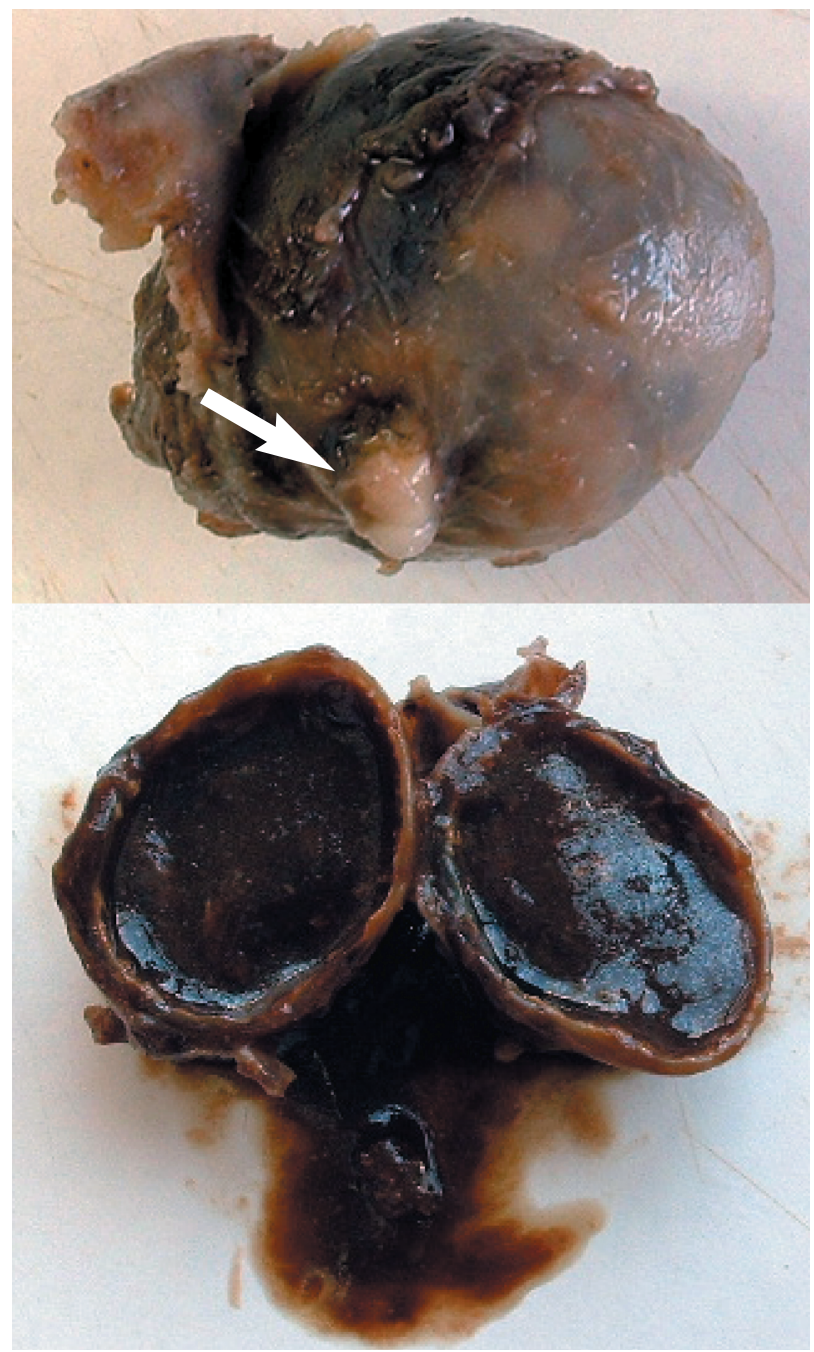

Figura 9. Vista macroscópica de pieza operatoria. Arriba se observa la lesión con una pequeña calcificación (flecha). Debajo, se observa contenido líquido color café parduzco.

Figure 9. Macroscopic view of surgical specimen. A small calcification can be observed above (arrow). Below, the liquid, brownish coffeecolored content can be observed.

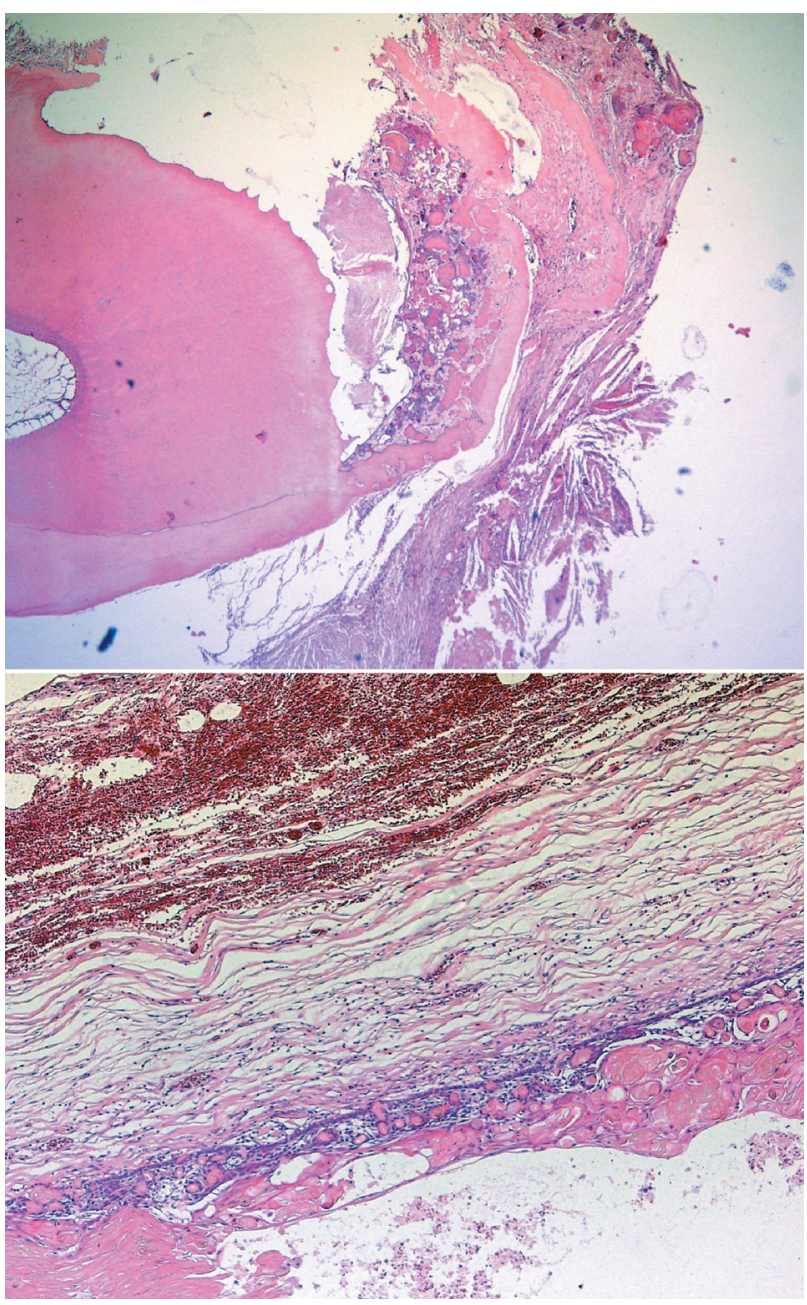

Figura 10. Estudio histopatológico. Arriba se observa cápsula fibrosa y epitelio constituido por células basales cúbicas. Debajo, adosado a la cápsula se ve un tejido mineralizado similar a una estructura dentaria.

Figure 10 Histopathologic study. The fibrous capsule can be observed above together with the epithelium made up of cuboidal basal cells. Mineralized tissue with a structure similar to dentine can be seen below attached to the capsule. el factor etiológico, es decir los remanentes epiteliales y su proceso quístico. En lesiones de gran tamaño pudiera realizarse un tratamiento descompresivo para posteriormente realizar la exéresis completa del quiste. ${ }^{24}$

Especial interés deriva de las posibilidades en la cicatrización y reparación del defecto óseo. Una cicatrización por primera intención en una cavidad con el tamaño del caso presentado aumenta mucho los riesgos de infección del coágulo. Por esta razón se decidió realizar un cierre por segunda intención a través de una gasa yodoformada, la que se fue retirando en forma progresiva, permitiendo un relleno continuo de la cavidad.

Creemos que en lesiones de este tamaño, en pacientes jóvenes y en tejido óseo maxilar no se requiere la utilización de injertos óseos primarios, pues el gran potencial reparativo y la indemnidad del periostio permiten una adecuada regeneración ósea. cal characteristics that distinguish it from a gingival fibroma, peripheral cyst or granuloma of giant cells.? Both are as common in the mandible as they are in the maxilla.

In this patient it was to be found in the incisor-canine area of the maxilla with this area of the maxilla being the most affected with a rate of $65 \%$ according to reports in the literature. 1,17,18

The age of the patient coincides with the prevalence reported by other authors, with the most prevalent age being between the $2^{\text {nd }}$ and $3^{\text {rd }}$ decade, and a mean age of 33 years. $1,17-19$

It has been associated with ameloblastoma, ameloblastic fibroma, and complex odontoma; the latter is to be found in younger patients in particular, such as in this case, representing 20 to $50 \%$ of the cases reported in the litera- 
La histología del QG generalmente consiste en una lesión quística envuelta en una cápsula fibrosa tapizada en su interior por una capa basal de células cilíndricas y luego varias capas celulares que semejan el retículo estrellado. El epitelio subyacente tiene la capacidad de inducir la formación de tejido dentario maduro en la pared de tejido conectivo. ${ }^{16,18}$ Es característico de esta lesión, la presencia de masas de células fantasmas ubicadas en el epitelio o en la cápsula que lo rodea.

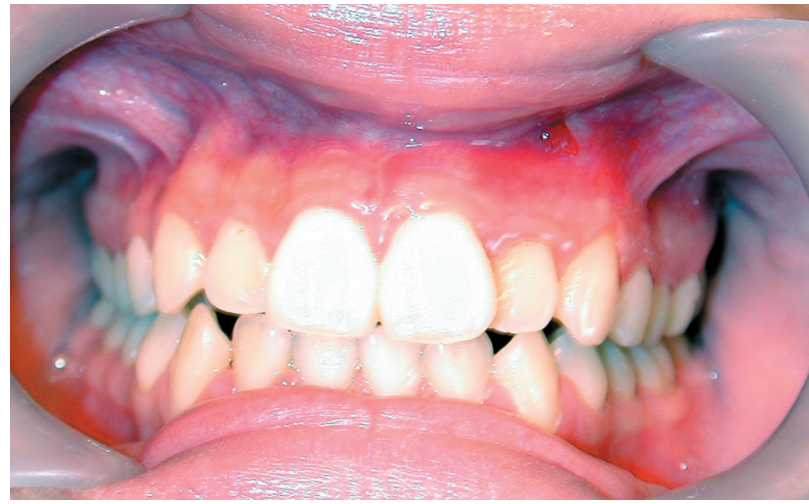

Figura 11. Oclusión dental postoperatiora. Figure 8. Postoperaty dental oclusion.

\section{Conclusiones}

El quiste de Gorlin es una lesión infrecuente en la patología quística de los maxilares.

El tratamiento de elección es siempre quirúrgico, consistiendo en la eliminación total de la lesión, con altas tasas de éxito y una mínima recidiva, cuando se ha realizado una correcta técnica quirúrgica.

\section{Bibliografía}

1. Neville BW, Damm DD, Allen CM, y cols. Oral and Maxillofacial Pathology. Philadelphia PA, Saunders, 1995; 506.

2. Curran A, Damm D, Drummonds J. Pathologically significant pericoronal lesions in adults: Histopathologic evaluation. J Oral Maxillofac Surg 2000;60:613-7.

3. Ko KS, Dover DG, Jordan RC. Bilateral dentigerous cysts, report of an unusual case and review of the literature. / Can Dent Assoc 1999;65:49-51.

4. Miller CS, Bean LR. Pericoronal radiolucencies with and without radiopacities. Dental Clin North Am 1994;38:51-61.

5. Ustuner E, Fitoz S, Atasoy C, y cols. Bilateral maxillary dentigerous cysts: A case report. Oral Surg Oral Med Oral Pathol Oral Radiol Endod 2003;95:632-5.

6. Sikes JW, Ghali GE, Troulis MJ. Expansile Intraosseous lesion of the maxilla. J Oral Maxillofac Surg 2000;58:1395-400.

7. Weber AL. Imaging of the cysts and odontogenic tumors of the jaw. Definition and classification. Radiol Clin North Am 1993;31:101-20.

8. Giansanti JS, Someren A, Waldron CA. Odontogenic adenomatoid tumor (adenoameloblastoma). Oral Surg 1979;30:69.

9. Lee JK, Lee KB, Hwang BN. Adenomatoid odontogenic tumor: A case report. J Oral Maxillofac Surg 2000;58:10.

10. Shear M. Developmental odontogenic cysts: An update. J Oral Pathol Med $1994 ; 23 ; 1$

11. Altini I, Farman AG. The calcifying odontogenic cyst: Eight new cases and review of the literature. Oral Surg Oral Med Oral Pathol 1975;40:751.

12. Hirshberg A, Kaplan I, Buchner A. Calcifying odontogenic cyst associated with odontoma: A possible separate entity (Odontocalcifying odontogenic cyst) J Oral Maxillofac Surg 1994;52:555.

13. Gorlin R, Pindborg JJ, Clausen FP, y cols. The calcifying odontogenic cyst: A possible analogue of the cutaneus calcifying epithelioma of Malherbe: An analysis of fifteen cases. Oral Surg 1962;15:1235. ture. ${ }^{1,11,18-21}$ The neoplastic variety is generally to be found in elderly patients although it is less common. ${ }^{1}$ The radiography does not show a typical image, as the image may be uni- or multilocular. The presence of calcifications of various sizes can be observed.

With regard to the therapeutic alternatives, all these are aimed at eliminating the etiological factor, that is, the epithelial remains and the cystic process. In larger sized lesions decompressive treatment can be carried out so that complete exeresis of the cyst can later be carried out. ${ }^{24}$

Of special interest are the possibilities of repairing the bone defect. First intention healing in a cavity of the size in this case increases the risk of clot infection. For this reason second intention healing was carried out by means of an iodoform gauze that was removed progressively, allowing the cavity to be always filled.

We believe that when located in maxillary bone tissue, primary bone grafts are not necessary for lesions of this size, in young patients as the considerable repair potential and the undamaged periosteum will allow proper bone regeneration.

The histology of the GC generally consists is a cystic lesion covered by a fibrous capsule and lined on the inside by a basal layer of cylindrical cells and then by various layers of cells that are similar to the stellate reticulum-type. The underlying epithelium is able to induce the formation of mature dental tissue in the wall of the connective tissue. ${ }^{16,18}$ The presence of masses with ghost cells situated in the epithelium or in the capsule that surrounds it, is a characteristic of this lesion.

\section{Conclusions}

Gorlin Cyst is an uncommon lesion in the cystic pathology of the maxilla. The treatment of choice is always surgical, and it consists in the total elimination of the lesion. If the surgical technique is correct, the success rates are high and relapse rates are minimal. 
14. Kramer IR; Pindborg J], Shear M. The WHO histological typing of odontogenic tumors. Cancer 1992;70:2988.

15. Hong DP, Ellis GL, Hartman KS. Calcifying odontogenic cyst: A review of ninety-two cases with reevaluation of their nature as cysts or neoplasms, the nature of ghosts cells, and subclassification. Oral Surg Oral Med Oral Pathol 1991;72;56.

16. Praetorius F, Hjorting-Hansen E, Gorlin RJ, y cols. Calcifying odontogenic cyst: Range, variations and neoplastic potential. Acta Odontol Scand 1981;39:227.

17. Buchner A, Merrell PW, Carpenter WM, y cols. Central (intraosseous) calcifying odontogenic cyst. Int J Oral Maxillofacial Surg 1990; 19:269.

18. Buchner A. The central (intraosseous) calcifying odontogenic cysts: An analysis of 215 cases. J Oral Maxillofac Surg 1991;49:330.

19. Johnson A, Fletcher M, Gold L, Chen S-Y. Calcifying odontogenic cyst: a clinicopathologic study of 57 cases with immunohistoche- mical evaluation for cytokeratin. J Oral Maxillofac Surg 1997; 55:67983.

20. Keszler A, Guglielmotti MB. Calcifying odontogenic cysts associated with odontoma: Report of two cases. J Oral Maxillofac Surg 1987;45: 457.

21. Moleri AB, Moreira LC, Carvalho JJ. Comparative morphology of 7 new cases of calcifying odontogenic cysts. J Oral Maxillofac Surg 2002;60:689-96.

22. Freedman PD, Lumerman H, Gee Jk. Calcifying odontogenic cyst: $A$ review and analysis of seventy cases. Oral Surg Oral Med Oral Pathol 1975;40:93.

23. Pistóia G, Gerlach R, Dos Santos JC, Montebelo FA. Odontoma-producing intraosseous calcifying odontogenic cyst: Case Report. Braz Dent J 2001;12:67-70.

24. Vivas M, Brizual LM, Toro R. Decompression and secondary enucleation: An alternative treatment in large cystic lesions. J Oral Maxillofac Surg 2004;62:28. 